Olguta Lupu

National University of Music

Bucharest

Romania
UDC: 78.071.1:929 Olah T.

78.071.1:929 Vieru A.

doi:10.5937/ZbAkUm1907062L

Original scientific paper

\title{
The Symbiosis between Tradition and Modernity in the Works of Tiberiu Olah and Anatol Vieru
}

\begin{abstract}
The apparently antagonistic relation 'tradition - innovation' lays at the foundation of European art music as permanent transfer, as a complementary binomial. In higher education music institutions, there is also a strong connection between tradition and innovation. This paper focuses on the creation of two Romanian composers, Tiberiu Olah and Anatol Vieru (who were teachers at the Bucharest Conservatory, as well), aiming to emphasize their personal ways of balancing the new and the old. The modal universe, with its immense potential, becomes their object of study and their most important source of inspiration. The tie with the musical past is manifest, in the works of Olah and Vieru, in three main directions: a) the innovative absorption of aspects of Romanian oral tradition; b) the return to consonance; c) the references to the tradition of European art music.
\end{abstract}

Keywords: Tiberiu Olah, Anatol Vieru, modes, serialism, quotation

Associations of such notions as tradition - innovation, national - universal etc. were often considered antagonistic binomials, causing tensions and apparently irreconcilable conflicts. In fact, in duos of this kind, the respective items can be seen as complementary, acting interdependently, one fuelling the other, and making therefore the border between them difficult to place.

The relation tradition - innovation lays at the foundation of European art music not only as opposition, but also as permanent transfer, for what had at one point been revolutionary later became, by cultural validation, tradition, and the re-evaluation of forgotten traditions was a part of the modern times' contribution: „The history of tradition $[\ldots]$ proves that it manifests, in fact, as accumulation of innovation, as history of [...] investigations, and not in the least as inventory of immutable dogma" (Olah, 2008/1975: 64). In musical performance, the vision adapted to the present times is now, strangely enough, considered 'conventional', and the 'historically informed' performance is seen as representing the true change:,,the ancients and moderns ought to exchange labels. 
What is usually called 'modern performance' is in fact an ancient style, and what is usually called "historically authentic performance" is in fact a modern style" (Taruskin 1992: 311). Even within oral traditions there is a continuous adaptation to the present moment, whose specific reshapes the past to a lesser or greater extent: „tradition not only serves modernity, but the modern contexts [...] serve tradition" (Sutton, 2006: 19).

The contradiction (rather, cohabitation) 'tradition - innovation' can also be identified in music education, where tradition has always been attended to, many prestigious music teaching centres succeeding in filtering and communicating the perennial values of music. At the same time, the Conservatory, despite its name which, apparently, firmly positions it in 'the past', represents the place where acclaimed figures from among the most innovative, teachers and students alike, work and study. As well, the Conservatory as institution cannot be isolated from its socio-political context: „Institutions [...] foster their own important processes of musical transmission: not just in terms of the institutions themselves, but also in how they relate to the social and political forces that use and shape them" (Cohen, 2009: 323).

In his analysis of the connection between tradition and innovation in higher education music institutions, Anatol Vieru argues it is precisely the symbiosis between them which needs to be cultivated: ,we must try to see the modernity of classical music, just as we must try to discover, in the great contemporary music works, the link to Classicism, to tradition" (Vieru, 1994: 380).

In Romania, in the context of the new Communist political regime taking power in 1944, the natural relation between tradition and innovation is upset by the intrusion of ideology in this field. The socialist realism doctrine proclaims art as ,a means of creating the new man"(Sandu-Dediu, 2002: 11-12), eliminating the possibility of any autonomous art. The new political power divides music into two categories: 'progressive' (that is, the simplistic mass music, promoting the revolutionary patriotic élan by such means as facile tonalism and the turning of folklore into an empty stereotype), and 'decadent' or 'reactionary' (that is, the avant-garde music, characterised by modern writing techniques and cultivating complexity, chromaticism, dissonance). After a first period of major turbulences (1944-1954), the situation improves, remaining nevertheless far from normal.

Despite these unfavourable conditions, some names among the new members of the Composers' Union would stand out and would soon become landmarks of modernism in Romanian music: Anatol Vieru, Cornel Țăranu, Myriam Marbe, Pascal Bentoiu, Tiberiu Olah, Aurel Stroe, Ștefan Niculescu etc.

Tiberiu Olah and Anatol Vieru earned a grant to study at the Moscow Conservatory between 1949 - 1954 and 1951 - 1954, respectively. Even if the sociopolitical circumstances ideologised music education, the Tchaikovsky Conservatory had managed to remain an oasis of professionalism. In an interview from 1998, Olah sketches 
the atmosphere in an institution where the perpetuation of fine tradition coexisted with the underground promotion of banned new music: ,At a time when in Romania the political side, that of illiterate activism, predominated [...], a traditional conservatory endured over there, a conservatory in the best and strictest sense of the word. [...] [W]ith all the restrictions applied to the library's secret fund, there was also a tacit conspiracy in to the 'circulation' of the scores" (Olah, in Cengher, 2008/1998: 268-69).

Upon their return to Romania, Olah and Vieru joined a group of young composers extremely interested in avant-garde music, of which Ștefan Niculescu, Myriam Marbe, Aurel Stroe and others were a part. The musicologists remark on the extraordinary solidarity of this group, which no other generation of Romanian musicians possessed:,,they are always present when a colleague has his works performed, [...] they take part, as a group with shared opinions, in the musical gatherings of the [Romanian Composers'] Union“ (Sandu-Dediu, 2002: 25).The members of this group didn't remain stuck in sterile experiments. Their vast musical culture allows them a nuanced perspective on music and its continuities and discontinuities throughout history, on the valuable innovations which become tradition, on the 'minor' experiments which remained simple curiosities (Olah, 2008/1975: 64). The new Western total serialism trend only occasionally attracts them, insofar as it symbolises the protest and resistance to the cultural values promoted by the Communist regime. Like their contemporaries, Olah and Vieru are interested in finding unconventional modalities of exploiting the musical oral and written traditions (Sandu-Dediu, 2002: 164). The modal universe, with its immense potential, proven time and again by ancient or recent history, becomes their object of study and their most important source of inspiration.

We can argue that the tie with the musical past is manifest, in the works of Olah and Vieru, in three main directions: a) the innovative absorption of aspects of Romanian oral tradition; $b$ ) the return to consonance; $c$ ) the references to the tradition of European art music.

\section{The innovative absorption of aspects of Romanian oral tradition}

In Romania, oral tradition took, and still takes, two forms, that of village folklore and that of Byzantine church music. In contrast to Ștefan Niculescu, for example, who constantly refers to the Byzantine tradition, Olah and Vieru are interested in the village folklore - not as a mechanical repetition of folk intonations, however, but as their decantation, essentialised expression, and transfiguration, striving to find the balance between the diatonicism of the micro-structure and the chromatic complexity of the macro-structure.

For both composers, the pre-pentatonic modes are a first nucleus and a starting point in building complex sound architectures. For instance, Olah uses the same three- 
sound melodic cell $(\mathrm{C}-\mathrm{F}$ sharp $-\mathrm{G})$ both in the second movement of his Cantata for Women's Choir (1956) and in the cycle Homage to Brâncuși, the structure becoming clearer in some of the pieces of the cycle (The Infinite Column - 1962, The Gate of the Kiss - 1965 or The Table of Silence ${ }^{1}$ - 1968). The characteristic feature of this cell is the augmented fourth, also called a Bihor fourth (after the Romanian Bihor county), in which Olah manifested a particular interest not only because it was specific to his home region, but also because there it wasn't perceived as a dissonant interval which needs to be resolved.

In the Cantata for Women's Choir, merging the two versions of the cell by placing the half step either at the bottom or at the top results in a four-sound structure (Ex. 1) which „constitutes the foundation of the whole movement“(Olah, 1960).

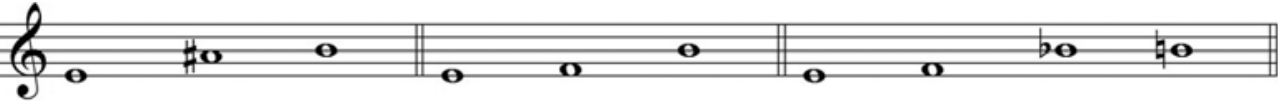

\section{Example 1. Olah, Cantata for Women's Choir, construction of the generative structure}

But this generating structure allows the composer to reach, over 14 bars, by means of transposing it on different steps, the chromatic whole, prohibited at the time, and at which he arrives not only through serial methods, but by using the modal technique - a subterfuge meant not only to bypass the censure (see Sandu-Dediu 2002: 25 ), but also to suggest new ways of creating complex musical structures.

Even if The Infinite Column starts with the same melodic configuration, the preference for a spatialized layout results, in addition to an allusion to the 'gălăua' formula (to be found in the tulnic signals specific to the Apuseni Mountains, see Draga 2008/1966: 355-356), in evading the half step - an option which would reappear in Olah's oeuvre (Ex. 2):

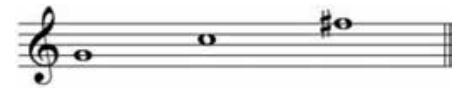

\section{Example 2. Olah, generative formula in The Infinite Column}

The finale presents the reunion of the different transpositions of the generating cell, resulting in the display of a chromatic whole organised in three segments (Ex. 3): A - B flat - D sharp - E (the extreme high register), G - A flat - C sharp - D (higher register), $\mathrm{F}-\mathrm{F}$ sharp - B - C (mid-lower register).

1 See Corneliu Dan Georgescu, 2008/1971: 389. 


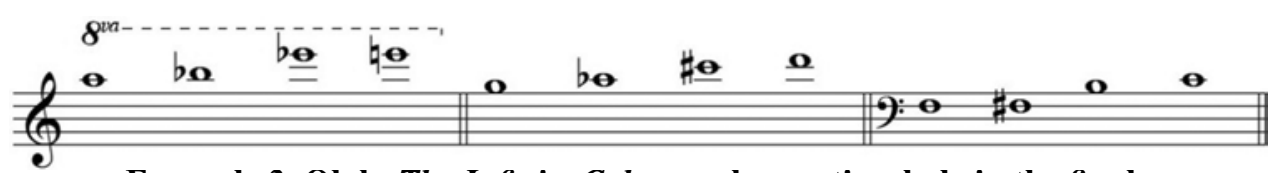

Example 3. Olah, The Infinite Column, chromatic whole in the finale

We see in Anatol Vieru's oeuvre, too, pre-pentatonic melodic structures, which serve as a starting point in building large works. As such, the theme of the Cello Concerto (1962) is a tetratonic scale with an augmented fourth and minor seventh (the essentialised expression of the Lydian-Mixolydian mode, Ex. 4a), and along the way the suggestion of a lullaby (the F sharp - A - B - C sharp tetratonic scale, Ex. 4b) appears. In his Fifth Symphony (1985), the theme of the second movement (Carols, Carols) is a Lydian tetratonic scale dans le caractère populaire roumain (Ex. 4c), as Enescu would say.

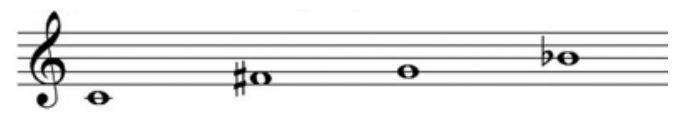

Example 4a. Vieru, Cello Concerto, 1st mvt., tetratonic scale

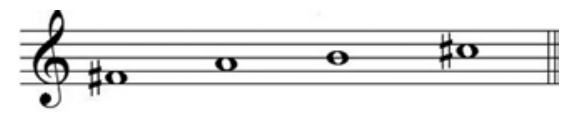

Example 4b. Vieru, Cello Concerto, 2nd mvt., tetratonic scale

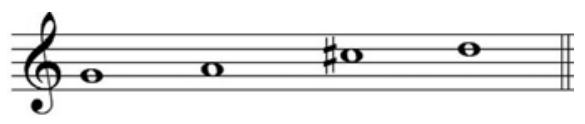

Example 4c. Vieru, The Fifth Symphony, 2nd mvt, tetratonic scale

Vieru also turns to intonations or rhythms from the children's folklore, by means of which he introduces a touch of ludic, candour, and nostalgia. In Games for Piano and Orchestra (1963), Vieru inserts, in the section Children Playing, the song Paparuda, pulverised and as if broken into small pieces, but still recognizable. And the third movement of his Sinfonia concertante for Cello and Orchestra (1987) contains melodic and rhythmic fragments which send us to bichord structures of Romanian children's songs such as Lună, lună nouă (New Moon, New Moon), Melc, melc codobelc (Snail, Snail) or Sorcova veselă (Budded Twig, Tender Green).

The isles of straightforwardness created by these structures counterbalance the complex approach to the sound material (transposition, transformation, superposition and various mathematical operations). We might argue that complexity is based on pre-pentatonic modes, validating and organising it. ${ }^{2}$ Because for Vieru, the creator of 2 The motif of the Paparude rain incantation "represents the fundamental proto-mode of the entire 
one of the most clearly articulated theories in the $20^{\text {th }}$ century music (Vieru 1980), the pre-pentatonic modes do not have the pejorative connotations associated to the phrase 'defective modes'. On the contrary. In one of his studies, the composer highlights the benefits of these modes: the smaller the number of elements, the greater the possibilities to include, in a single mode, more elements, thus increasing the degree of ambiguity and therefore of evocativeness: "In the existence of each mode there is expressed a certain equilibrium force of compensation: its ambiguity (let's call it the power of 'waiting') is compensated with the power of containing other modes" (Vieru, 1993/1978: 137). In Vieru's opinion, 'defective' modes "are surrounded by an aura of suggestion which the imagination will complete" (Vieru, 1993/1978: 137).

Vieru also incorporates melodies in Romanian folk style based on modes with more than four sounds, such as the two diatonic themes from his Concerto for Violin, Cello and Orchestra (1979), which bring to mind the sârbă folk dance. In the first movement, the cello plays theme 1 (bars $6-10$ ) and the violin, theme 2 (bars 14 - 19) (Ex. 5). In the third movement, by superposing the two themes (bars 19-23) in a typically Bartókian manner of creating a polymodal chromaticism, he obtains an eleven-sound scale.
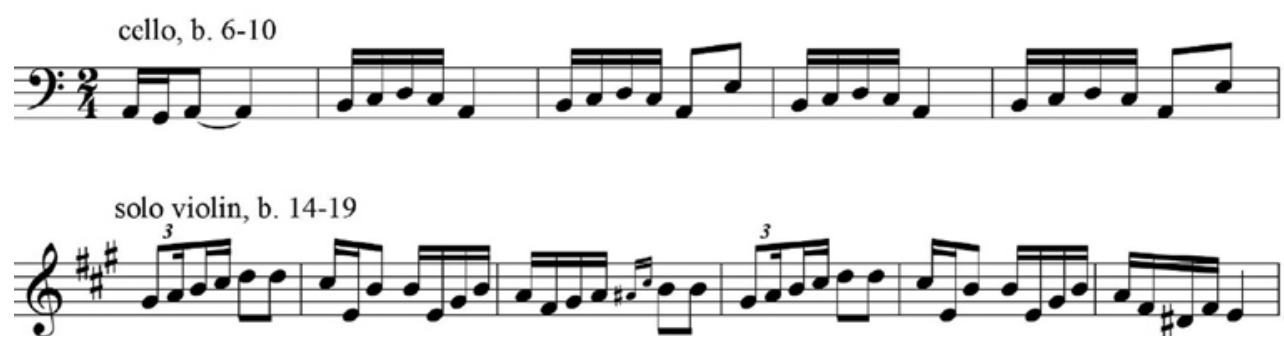

Example 5. Vieru, Concerto for Violin, Cello and Orchestra, 1st mvt, themes 1 and 2

The absences of the chromatic whole is compensated by the resulting symmetry, the 11 sounds forming a mode with non-retrogradable structure: 11111211111 (Ex. 6).

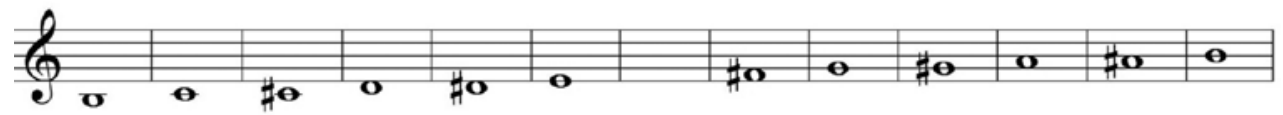

Example 6. Vieru, Concerto for Violin, Cello and Orchestra, scale resulted from the superposition of the two themes

musical edifice" (Vieru, 2006a: 68). 
And in The Shell (1981), initially called Monograph of Sârbova Village, Vieru incorporates all 70 melodies from the Nicolae Ursu collection; even if they are quoted as such, the melodies are in fact 'hidden', as they are superposed and marked pppp sul tasto (that is, a minimal volume), resulting, in the composer's own words (Vieru, 1993: 178), in a white noise, from which certain fragments would sometimes surface and of which, once in a while, a melody would fight its way out by a sudden volume change (forte).

\section{The return to consonance}

In the 60s, minimalism(Reich, Riley, Glass) meant the rise of an iconoclasm-tinged movement advocating the return to consonance and repetition, as a counteroffensive to the emancipation of dissonance and non-repetitiveness which had marked the beginning of the $20^{\text {th }}$ century. In the $70 \mathrm{~s}$, the current reaches Europe too, in the form of the new simplicity, supported by composers who had previously chosen different stylistic coordinates (Gorecki, Pärt).

We can point out to several interesting congruencies between this current and the works of Olah and Vieru. Still, the idea of reclaiming some traditional structures does not, for them, represent a major change in evolution of their style. Because, as noted, Olah and Vieru had already investigated, as early as the 50s, various modalities of absorbing Romanian folk music intonations. Moreover, for the two composers, as for all members of the above-mentioned group for that matter, researching tradition also meant identifying some ways to integrate it into a modern language. As such, in the 70s and the 80 s the stress shifts from structures characteristic to a smaller geographical area, to traditional structures without a clearly defined local flavour. As if to give an answer to the rhetorical question Jean Claude Éloy asked (Damian, Éloy, et al., 1988, quoted by Popovici, 2008/1989: 460): „What can one do today, if one rejects the wonders of electronics, with the twelve tones one inherited, if one wishes neither to resuscitate Postserialism, nor to fall prey to Neo-tonalism nostalgia?," the two composers try on new paths to a creative recuperation of two universal, archetypal sound structures: thetriad (major, with Olah; major and minor with Vieru) and the pentatonic scale.

In the second half of the $20^{\text {th }}$ century, the major triad was one of the preferred structures in American minimalism. There is, though, a consistent distance between the repetitive patterns used in the American music of the $60 \mathrm{~s}^{3}$ and the complex manner in which the major chord archetype is integrated and reworked by the two Romanian authors.

Vieru's preference for major and minor chords ties him, according to musicologist H. Halbreich, to the new consonantism (Vieru, 1993: 238). In the second movement of his 1979 Concerto for Violin and Cello (section B), major minor seventh chords are

3 In a radio conference, Vieru observes: "Part of repetitive music has become an excuse for lazy thinking”(Vieru, 2006b: 172). 
played by the solo violin in a manner which rather sends us to the modal world (one similar to the tulnic signals from the Apuseni Mountains). The chords are translated from third to third, suggesting the axis system theorized by Ernö Lendvai in Bartók's oeuvre. This shift generates not only the diatonic chromaticism, but a total of 11 tones as well, forming a mode with the same non-retrogradable structure: 11111211111 (Ex. 7). The 'omitted' tone (F sharp) is nevertheless present in the solo cello pentatonic scale, on which the solo violin is stacked.
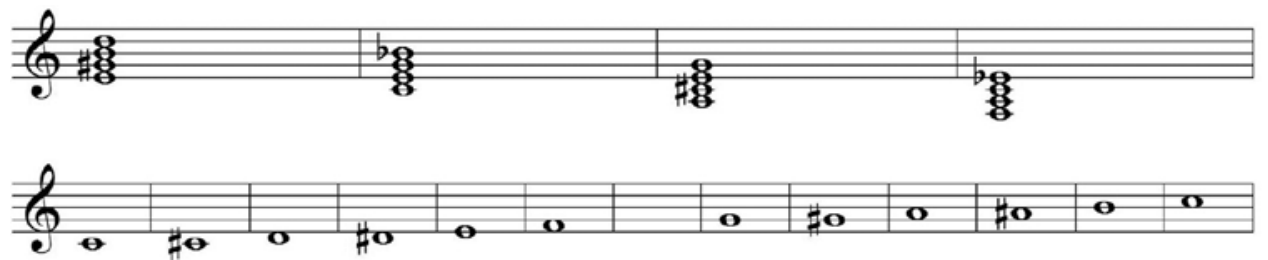

\section{Example 7. Vieru, Concerto for Violin and Cello, 2nd mvt, chords and scale resulted}

Vieru uses the major and minor chords in other works as well. For instance, in his Psalm 1993 for orchestra, the composer starts from four harmonic composites, each obtained by the superposition of two consonant triads (one major and one minor):

\begin{tabular}{|c|c|c|c|}
\hline Chord composite 1 & Chord composite 2 & Chord composite 3 & Chord composite 4 \\
\hline minor triad on $\mathrm{E}$ & minor triad on $\mathrm{D}$ & minor triad on $\mathrm{A}$ & minor triad on $\mathrm{C}$ \\
\hline major triad on $\mathrm{F}$ & major triad on $\mathrm{G}$ & major triad on $\mathrm{C}$ & major triad on $\mathrm{A}$ \\
\hline
\end{tabular}

And in the Psalm from his second symphony, all 12 major chords progress as a descending fifths sequence.

In the first movement of Symphony no. 5, the vocabulary is constituted of major and minor chords again built on each of the 12 steps of the chromatic scale, in a sequence of perfect fifths. In movements 2 to 4 only some of the 24 triads from the first movement are selected.

Other times Vieru arranges these structures horizontally, creating melodies by the concatenation and rhythmization of some major or minor arpeggios (complete or indeterminate), as is the case of the third movement of Symphony No. 5 (Ex. 8).

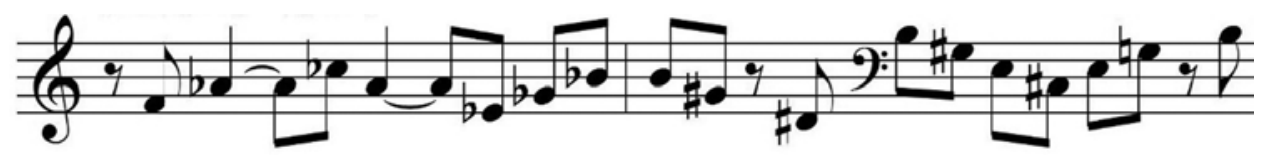

Example 8. Vieru, Symphony No. 5, 3rd mvt, major and minor arpeggios 
It is worth noticing that major arpeggios are present in Vieru's oeuvre as early as the $6^{\text {th }}$ decade of the past century. Even if his first Concerto for Flute (1958) is a serial work, the composer brings, in the final movement, major arpeggios placed at an augmented fourth ${ }^{4}$, which he playfully alternates with Enescian chromatic intonations (various transposition of the Enescian cryptogram G-E-EsC $\mathrm{C}^{5}$, in fact existing in the series on which the work is based on), reaching the chromatic whole in about 3 bars (Ex. 9).

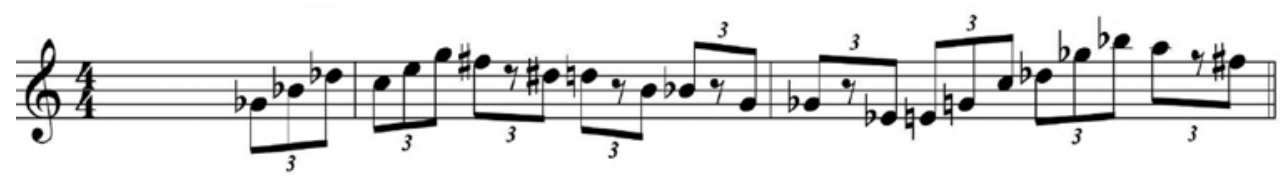

\section{Example 9. Vieru, Concerto for Flute, 3rd mvt, major arpeggios and Enescian cryptogram}

Olah becomes interested in absorbing the major chord or the pentatonic scale later. Two are the works which give us hints as to the exploitation of these sound materials as early as the title: Symphony No. 2, Adventures with Major Triads and Pentatonic Scales (1986) and the wind quintet Adventures with Major Triads (1993). But the idea of using a diffused pentatonic scale, rendered complex by means of superposition, is present in other works as well: the cycle Rhymes for the Revelation of Time (which includes Rhymes I, sonata for clarinet and magnetic tape, 1982; Rhymes II for saxophone and tape, 1984; Rhymes III, sonata for violin, percussion and tape, 1999), Incontri spaziali (1989) etc.

We must point out that for Olah the major chord and the pentatonic scale are not distinct, but related structures, as in his view the major chord represents the simplified form of the pentatonic scale (Olah, in Manolache, 2008/1991: 257).

To illustrate this, I have chosen the wind quintet Adventures with Major Triads, which begins with several major arpeggios spaced along registers and timbres, which engender, by intersection, minor arpeggios. Similar to his Second Symphony, Olah 'introduces' the characters in the first movement, all 12 major arpeggios entering the stage in chromatic succession from $\mathrm{C}$ to $\mathrm{B}$ and arriving at the chromatic whole in bar 17 (after the exposition of the first five chords). Olah insists on the tension (of Bartókian, but also Stravinskian inspiration), the outcome of the chromatic clash between two diatonic structures (major arpeggios placed at a minor second, Ex. 10).

4 It is interesting to note the similarity with the way Stravinsky too superposes in Petrushka (the theme of the main character) two major chords placed at an augmented fourth.

5 Derived by George Enescu from his own name - G(eorge)-E(n)-Es-C(u) and which he used in a multitude of forms. 


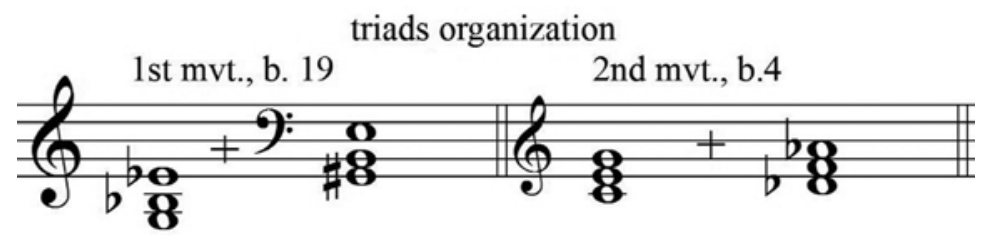

Example 10. Olah, Adventures with Major Triads

The references to the tradition of European art music

Quoting in classical music composition is by no means a new idea. From the Gregorian musical phrase 'Dies irae' to the Lutheran chorale in Bach's works, from themes on which large variational forms are based to landmarks of the $20^{\text {th }}$ century (Berio's Sinfonia), quotation is one of the customary formulas by means of which tradition conjugates with innovation and, as a rule, the present's way of honouring the past.

But, of course, no matter how familiar the quotation, its insertion into a different context will create the premises of alterity. As such, ,any quotation will be a hypostatization of the couple familiarity - otherness" (Lupu, 2016: 269). Besides, by this deliberate insertion the composer also assumes an ensemble of cultural associations and meanings, creating connections which „,an range from assertion (the quotation represents the work, supports its meaning, resonates with it) to denial (the quotation is deformed, parodied, placed in a divergent context) or problematization (reflection, debate, and taking into discussion - the most germinating attitude in the defamiliarization process)“(Lupu, 2018: 109).

Vieru's art music quotations come from a period going back to the Baroque. Museum Music (1968) for harpsichord and orchestra begins with, and refers to, Bach's Prelude in C major in the first book of the Well-Tempered Clavier. In The Sieve of Eratosthenes (1969), conceived ,as a sort of comedy of prime numbers" (Vieru, 1993: 215), to each prime number a different musical structure is assigned; to the prime numbers from 11 to 37, Vieru associates selections from Beethoven's Moonlight Sonata (number 11), Sarasate's Zigeunerweisen (13), Mozart's Clarinet Concerto (17), Beethoven's Trio in C minor (19), Bach's Partita in G major for solo cello (19), continuing with fragments from his own or his contemporaries' works. In his Screen (1970), the composer implants, after the golden ratio, bits of Skriabin's Poème de l'extase (Vieru, 1993: 218), Vieru being a great admirer of, and an expert in, the Russian author's oeuvre.

In Narration II for saxophone and orchestra (1985), Vieru creates a multilayered dialogue between past and present by inserting the children's song Frère 
Jacques. ${ }^{6}$ First presented in a version very close to the original (Ex. 11), it undergoes various stages of deformation, including the use of microtones (Ex. 12), causing it to be reiterated, at the end, in a uniform quarter notes rhythm (Ex. 13) suggestive of Berg's invention in uniform eighth notes rhythm from Wozzeck.

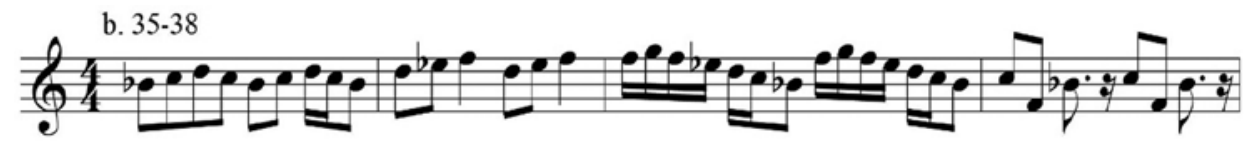

Example 11. Vieru, Narration II, the first quotation of the song Frère Jacques
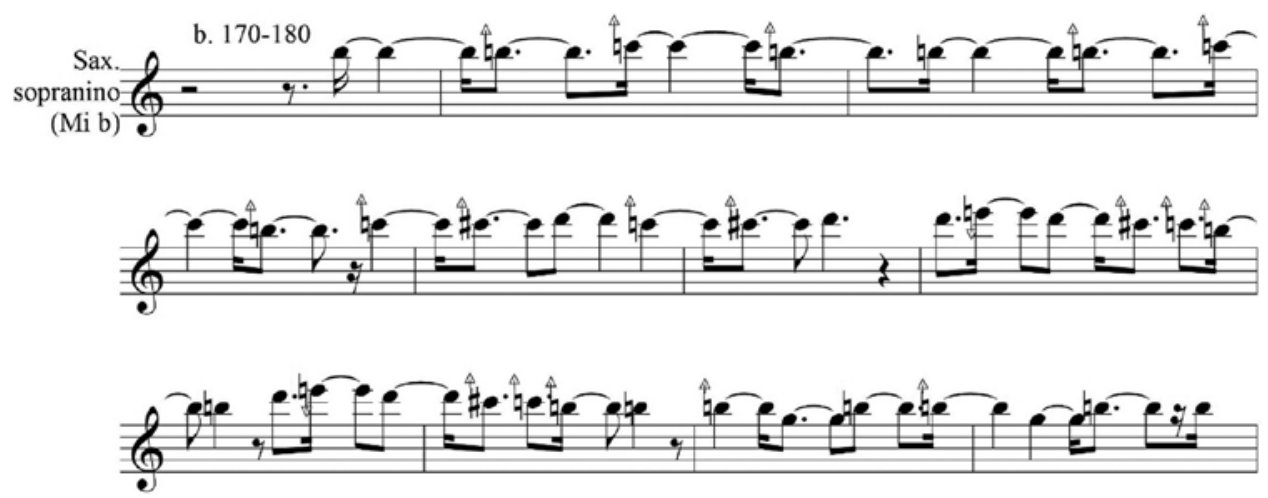

Example 12. Vieru, Narration II, deformation of the song Frère Jacques
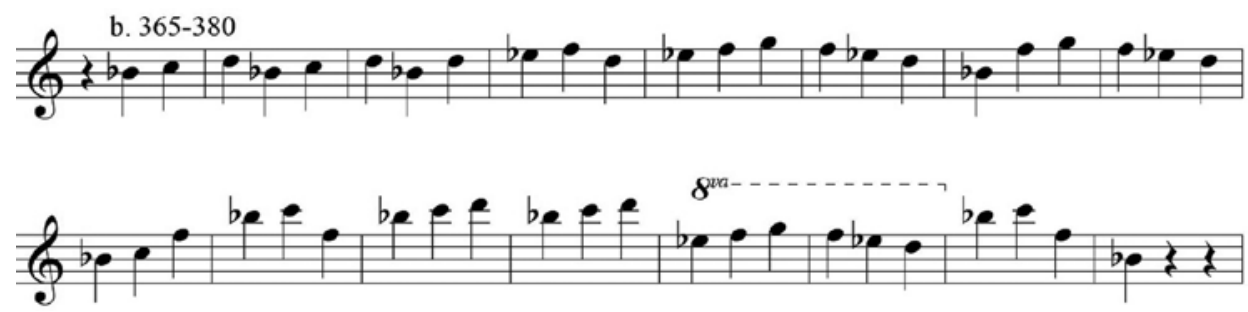

Example 13. Vieru, Narration II, final quotation of the song Frère Jacques

6 Speaking about his work, Vieru once briefly said it employs a "French folk song" (see Vieru, 2006a: 86). 
Several characteristics distinguish Narration II.

a) It allows melody (ancient form of musical organisation, but reluctantly used in the $20^{\text {th }}$ century music) to play an important role, in the form of quotation which in its turn directs the construction of the work.

b) It tests a border area situated between traditional and art music, Frère Jacques being a common good of European culture while also bearing the mark of Rameau ${ }^{7}$ and Mahler (Symphony No. 1).

c) It sparks off a mass of heterogeneous correlations, by quoting a very familiar song loaded, for the knowledgeable music lover, both with the associations induced by the music and the satirical text, and with the sombre, tragic mood with which Mahler had vested it.

d) It is a possible vehicle for expressing or engendering subversive meanings, as the song's lyrics ${ }^{8}$ presented, in the context of the Communist regime, curious similarities with the Romanian song Awaken, Romanian / From Thy Deathly Sleep, at that time banned (and currently Romania's National Anthem).

The fact that Narration II is placed in the proximity of the opera The Paupers' Feast and of the three mini-operas inspired by the works of Caragiale ${ }^{9}$ supports the hypothesis that Vieru wanted to create some extra-musical connotations which catch the essence of the Zeitgeist, of smiling through tears, of that mix between the satirical and the tragic which defined the respective socio-political context and which is also present in the historical evolution of the song (by the inversion of meaning operated by Mahler).

Olah, too, exercised incorporating European art music quotations. Such works as PaROdiSSINIana (1973), a musical joke on themes by Rossini, Metamorphosis on a Capriccio by Paganini (1980), or Harmonies IV (1981), which quotes a fragment from Enescu's Chamber Symphony, are several first attempts to it, the idea growing later in a series of works of remarkably dramatic force: Symphony No. 3 - Metamorphoses on Moonlight Sonata (1989), Obelisque for Wolfgang Amadeus (1991), and Sinfonia giocosa?! (1991).

If I illustrated Vieru's case with a work written during the Communist dictatorship, I will analyse Olah's by means of a piece composed soon after the events of December 1989: Sinfonia giocosa?!, whose title, both inciting and problematizing, brings the affirmation ('Sinfonia giocosa') face to face with its questioning (through the punctuation marks '?!').

7 Sylvie Bouissouargues that the paternity of this song belongs to Rameau (Bouissou, 2014).

8 Usually translated as Are you sleeping? Are you sleeping? / Brother John, Brother John, / Morning bells are ringing! Morning bells are ringing! / Ding, dang, dong. Ding, dang, dong.

9 Vieru writes between 1982 and 1984 three mini-operas with satirical connotations, inspired by the works of Ion Luca Caragiale (Telegrams, Theme and Variations, A Modern Teacher). 
As in Vieru's Narration II, at the foundation of the entire work lays a very easily recognizable quotation in the European cultural space, namely, a fragment from Ode to Joy. But it is not revealed as such until the Coda of the final movement, and even then it is still deformed by rhythmic augmentations and insertions of rests which create an atmosphere of reflection and interrogation apparently contradicting the Beethovenian quotation (Ex. 14).

\section{Beethoven, final movement}

Allegro assai

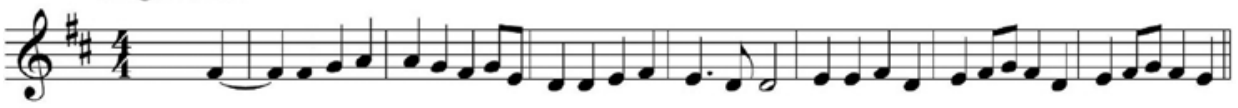

Olah, 3rd movement, b. 126-136

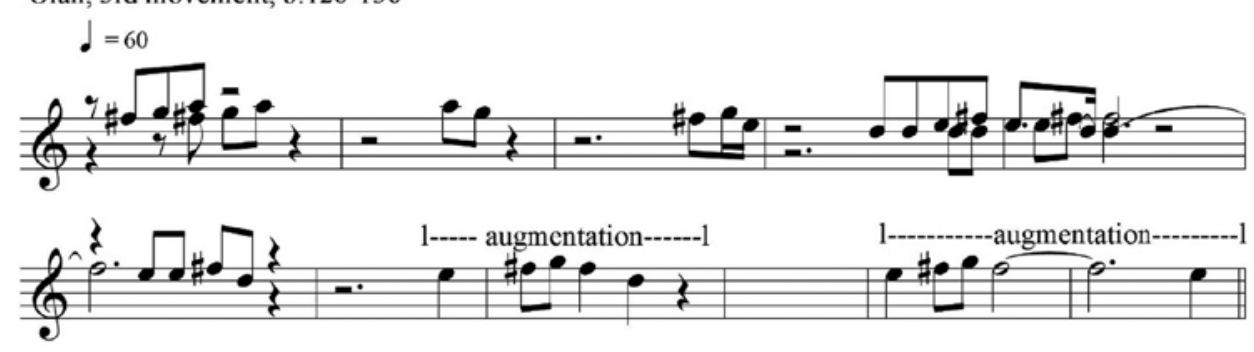

\section{Example 14. Beethoven, Ode to Joy, and its quotation in Olah, Sinfonia giocosa?!}

The exposition of the fragment in fact constitutes the end of a sinuous process of a gradual reconstruction of the musical phrase, starting by its constituent elements: the diatonic trichord in its three stages (half step - whole step; whole step - half step; whole step - whole step), exhausting the possible combinations of European twelvetone equal temperament. Olah thus objectifies the Beethovenian sound material, proving it to be of archetypal structures descent (Ex. 15a, b).

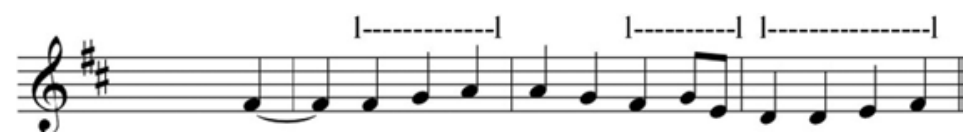

Example 15a. trichordal structures in Ode to Joy 


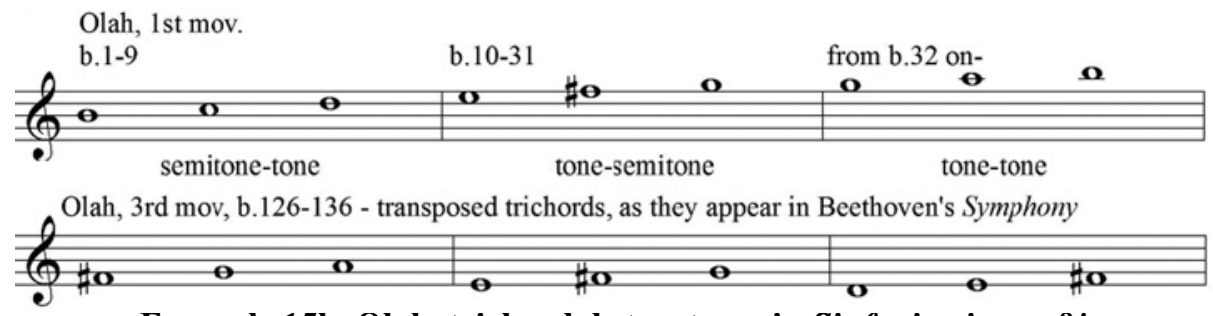

Example 15b. Olah, trichordal structures in Sinfonia giocosa?!

And this is but one of his goals. By decomposing the Beethovenian theme into archetypal components, Olah also verifies the uniqueness of European music. For all along the voyage of recomposing the original, he inserts many other fragments, selected on one single criterion - the trichord as common generating structure: the beginning of the overture to Verdi's La forza del destino, a symbiosis between the two famous motifs from Beethoven's String Quartet No. 16 in F major, Op. 135, the fragment „The Trumpets Sound“" from Olah's soundtrack to Mihai Viteazul (see Lupu, 2016: 276-77), as well as a hexachord (Ex. 16) which represents both the concatenation of two trichords and the point of convergence reuniting three different works.

\begin{tabular}{|c|c|c|}
\hline $\begin{array}{c}\text { Genovese Psalm No. } 42 \text { (the first eight } \\
\text { sounds) }\end{array}$ & $\begin{array}{c}\text { Chaplin's Smile } \\
\text { (the first eight sounds) }\end{array}$ & $\begin{array}{c}\text { The Royal Anthem (the verse "The } \\
\text { Joyful Earthly Heaven") }\end{array}$ \\
\hline
\end{tabular}

\section{Example 16. Olah, other quotations in Sinfonia giocosa?!}

Olah selects quotations belonging to different historical and stylistic areas: opera (Verdi), film music (Chaplin, Olah); chamber music (Beethoven's Quartet Op. 135); orchestral music (Ode to Joy, Franck's Symphony); sacred music (Genovese Psalm); patriotic music (The Royal Anthem). Their common structure is the trichord, and bringing them together results in the same blend of tears and laughter I had pointed out in Vieru's Narration II, but on different coordinates. I asked myself what could be the meaning of this multitude of quotations, some of them explicit, others disguised, some of them audible, others hidden in the folds of the score? I believe that Olah's work can be considered as affirming genealogy, descent, the composer's cultural filiation, all quotations belonging to the great European musical family. But it is more than that. On another level of interpretation, this Sinfonia giocosa?! is a demonstration, with purely musical means, of the world's unity and inner coherence, more precisely that of the 
musical European world, occurring (not by accident, I think) in a moment in history when the Romanian nation was searching for its identity and trying to find where it belonged, after the events of December 1989. The work thus acquires a teleological, centripetal, organising function, being a step on the golden mean to transcend appearances and search for the essential.

Both as composers and as long-time teachers at the Bucharest Ciprian Porumbescu Conservatory, Anatol Vieru and Tiberiu Olah are benchmarks of blending tradition and innovation. In their double capacity, they proved that, in the hands of a master, tradition and innovation, far from being opposed, are like two organic interconnected chains which make up the DNA spiral. The destructive entropic growth characteristic of closed, isolated systems can only be avoided if between tradition and innovation a continuous communication settles in, whereby the two nurture and complement each other. As such, the history of music can be seen as a spiral of the dialogue between tradition and innovation, in a permanent quest for a negotiation between the irrepressible progress of the vectorial and the frozen perpetuity of circularity.

\section{REFERENCES:}

1. Bouissou, Sylvie. 2014. Jean-Philippe Rameau. Paris: Fayard.

2. Cengher, Monica. 2008. „Tiberiu Olah la 70 de ani. Muzica îndeamnă la introspecție” ["Tiberiu Olah On His $70^{\text {th }}$ Anniversary. Music Urges Us to Introspect"]. In Tiberiu Olah Restituiri [Tiberiu Olah - Restitutions ], edited by Olguța Lupu, 268-269. Bucharest: Editura Muzicală. Original version in Muzica, 1/1998, 376, Bucharest: Romanian Composers' and Musicologists' Union Press.

3. Cohen, Judah M. 2009. "Music Institutions and the Transmission of Tradition". In Ethnomusicology, 53(2), 308-325.

4. Damian, Jean-Michel; Éloy, Jean-Claude; Masson, Gérard; Kaltenecker, Martin. 1988. "Karlheinz Stockhausen, Myths and Metamorphoses." In Diapason-Harmonie, 341, 62-64.

5. Draga, George. 2008. „Coloana infinită de Tiberiu Olah”[“Tiberiu Olah's Endless Column”]. In Tiberiu Olah - Restituiri [Tiberiu Olah - Restitutions], edited by Olguţa Lupu, 354-362. Bucharest: Editura Muzicală. Original version in Muzica 9/1966, 4-7. Bucharest: Romanian Composers' and Musicologists' Union Press.

6. Georgescu, Corneliu Dan. 2008. „Masa tăcerii de Tiberiu Olah” [”Tiberiu Olah's Table of Silence"]. In Tiberiu Olah - Restituiri [Tiberiu Olah - Restitutions], edited by Olguța Lupu, 385-391. Bucharest: Editura Muzicală. Original version in Muzica 11/1971, 11-14. Bucharest: Romanian Composers' and Musicologists' Union Press.

7. Lupu, Olguța. 2016. “The Quotation in Tiberiu Olah's Sinfonia Giocosa (!?)”. In Studia Universitatis Babes-Bolyai, Musica, 61(1), 265-282.

8. Lupu, Olguța. 2018. "The Dissidence of Melody in Anatol Vieru's Oeuvre. Case Study: The Quotation of the 'Frère Jacques' Song”. In Studia Universitatis Babes-Bolyai, Musica, 63(1), $105-116$. 
9. Manolache, Laura. 2008. „Pe teme de creație. Convorbire cu compozitorul Tiberiu Olah” ["Talking Composition with Tiberiu Olah"]. In Tiberiu Olah - Restituiri [Tiberiu Olah Restitutions], edited by Olguța Lupu, 242-263. Bucharest: Editura Muzicală. Original version in Muzica 3/1991, 108-117. Bucharest: Romanian Composers' and Musicologists' Union Press.

10. Olah, Tiberiu. 1960. "Cuvânt înainte" ["Foreword"] to Cantata for Women's Choir. Bucharest: Editura Muzicală.

11. Olah, Tiberiu. 2008. „Pe tema experimentului în muzică” [“On Experiment in Music”]. In Tiberiu Olah - Restituiri [Tiberiu Olah - Restitutions], edited by Olguța Lupu, 64-69. Bucharest: Ed. Muzicală. Original version in Muzica 10/1975, 1-3. Bucharest: Romanian Composers' and Musicologists' Union Press.

12. Popovici, Fred. 2008. „Simfonia a II-a de Tiberiu Olah” [“Tiberiu Olah's Symphony No. 2”]. In Tiberiu Olah - Restituiri [Tiberiu Olah - Restitutions], edited by Olguța Lupu: 460-470. Bucharest: Editura Muzicală. Original version in Muzica, 3/1989, 9-14. Bucharest: U.C.M.R.*

13. Sandu-Dediu, Valentina. 2002. Muzica românească între 1944-2000. [Romanian Music Between 1944 and 2000]. Bucharest: Editura Muzicală

14. Sutton, Richard Anderson. 2006. "Tradition Serving Modernity? The Musical Lives of a Makassarese Drummer". In Asian Music, 37(1): 1-23.

15. Taruskin, Richard. 1992. "Tradition and Authority". In Early Music, 20(2), 311-314+317320+323-325. Oxford University Press.

16. Vieru, Anatol. 1993. "The Rehabilitation of the 'Defective' Modes". In The Book of Modes, 137-141. Bucharest: Romanian Composers' and Musicologists' Union Press. Original version: „Reabilitarea modurilor defective”. In Muzica 1/1978, Bucharest: Romanian Composers' and Musicologists' Union Press.

17. Vieru, Anatol. 1994. „Clasic și modern în Conservatorul de muzică” [“Classical and Modern in the Conservatory of Music"]. In Cuvinte despre sunete [Words About Sounds], 367-376. Bucharest: Cartea românească.

18. Vieru, Anatol. 1980. The Book of Modes. Bucharest: Romanian Composers' and Musicologists' Union Press.

19. Vieru, Anatol. 1993. The Book of Modes. I. From Modes to a Model of Intervallic Musical Thought. II. From Modes to Musical Time. English version by Yvonne Petrescu and Magda Morait. Bucharest: Romanian Composers' and Musicologists' Union Press.

20. Vieru, Anatol. 2006a. Anatol Vieru despre muzica sa [Anatol Vieru About His Music]. Edited by Nina Vieru. Bucharest: National University of Music Press.

21. Vieru, Anatol. 2006b. Atlas de muzică nouă [Atlas of the New Music]. Edited by Nina Vieru. Bucharest: National University of Music Press. 


\section{Simbioza tradicije i savremenog u delima Tiberiu Olaha i Anatola Vierua}

Apstrakt: Naizgled antagonistički odnos „tradicija - inovacija“ leži na temeljima evropske umetničke muzike kao trajne poveznice, kao komplementarni binom. I u institucijama za visoko muzičko obrazovanje postoji jaka veza između tradicije i inovacije. Ovaj rad se bavi stvaralaštvom dva rumunska kompozitora, Tiberiu Olaha i Anatola Vierua (koji su, takođe, bili predavači na Konzervatorijumu u Bukureštu), sa ciljem da naglasi njihove lične načine balansiranja novog i starog. Univerzum modalnosti, sa svojim ogromnim potencijalom, postaje njihov predmet proučavanja i najvažniji izvor inspiracije. Povezanost sa muzičkom prošlošću je očigledna u delima Olaha i Vierua u tri glavna pravca: a) u inovativnoj apsorpciji aspekata rumunske usmene folklorne tradicije; b) u povratku konsonancama; c) u upućivanju na tradiciju evropske umetničke muzike.

Ključne reči: Tiberiu Olah, Anatol Vieru, modusi, serijalizam, citat 